\title{
Penegakan Yurisdiksi Internasional Criminal Court atas Kejahatan Agresi Pasca Kampala Amendements Diadopsi dalam Rome Statute
}

\section{Apripari Irham}

Pascasarjana Ilmu Hukum Universitas Padjadjaran, Bandung, Indonesia E-mail: apripari18001@mail.unpad.ac.id

\begin{tabular}{|c|c|}
\hline Dikirim: $19 / 02 / 2020$ & Dipublikasi: 30/12/2020 \\
\hline Info Artikel & \multirow[b]{2}{*}{$\begin{array}{l}\text { Abstract } \\
\text { Until the entry into force of the Rome Statute, the definition of the crime } \\
\text { of aggression was not also found in it. This leaves the International } \\
\text { Criminal Court (ICC) without jurisdiction over crimes of aggression. } \\
\text { The absence of ICC jurisdiction over crimes of aggression has resulted } \\
\text { in military aggression that has not been processed by the ICC during the } \\
\text { time when the proxy war / cold war was initiated. This means that the } \\
\text { violation of delicto jus gentium juice is allowed even after the ICC has } \\
\text { been established. This study aims: (1) to identify and identify the } \\
\text { definition, limitations, and jurisdiction of the ICC for crimes of } \\
\text { aggression; and (2) to determine the enforcement of ICC jurisdiction } \\
\text { over crimes of aggression after the Kampala Amendments were adopted } \\
\text { into the Rome Statute. The research method uses a type of normative } \\
\text { research with a statutory approach and a historical approach. The } \\
\text { results show that the ICC's definition, limitations, and jurisdiction over } \\
\text { the crime of aggression have existed in the Rome Statute since Kampala } \\
\text { Amendments were adopted into the Rome Statute. However, until now } \\
\text { the enforcement of the ICC's jurisdiction over crimes of aggression has } \\
\text { not been carried out concretely. }\end{array}$} \\
\hline $\begin{array}{l}\text { Keywords: } \\
\text { Jurisdiction of } \\
\text { Internasional } \\
\text { Criminal Court; } \\
\text { Crimes of Aggeession; } \\
\text { Kampala } \\
\text { Amendments. }\end{array}$ & \\
\hline \multirow{6}{*}{$\begin{array}{l}\text { Kata Kunci: } \\
\text { Yurisdiksi Mahkamah } \\
\text { Pidana Internasional; } \\
\text { Kejahatan Agresi; } \\
\text { Amandemen } \\
\text { Kampala. }\end{array}$} & Abstrak \\
\hline & $\begin{array}{l}\text { Hingga berlakunya Statuta Roma, definisi kejahatan agresi tidak juga } \\
\text { ditemukan di dalamnya. Hal ini menyebabkan International Criminal }\end{array}$ \\
\hline & Court (ICC) tidak memiliki yurisdiksi atas kejahatan agresi. Tidak \\
\hline & adanya yurisdiksi ICC atas kejahatan agresi telah mengakibatkan agresi \\
\hline & $\begin{array}{l}\text { militer yang pernah berlangsung dalam kurun waktu dimulainya proxy } \\
\text { war / cold war tidak diproses oleh ICC. Keadaan demikian berarti }\end{array}$ \\
\hline & $\begin{array}{l}\text { pelanggaran terhadap delicto jus gentium dibiarkan sekalipun ICC telah } \\
\text { dibentuk. Penelitian ini bertujuan: (1) untuk mengetahui dan } \\
\text { mengidentifikasi defenisi, batasan serta yurisdiksi ICC atas kejahatan } \\
\text { agresi; dan (2) untuk mengetahui penegakan yursidiksi ICC atas } \\
\text { kejahatan agresi pasca Kampala Amendments diadopsi ke dalam Statuta } \\
\text { Roma. Metode penelitian menggunakan jenis penelitian normatif } \\
\text { dengan pendekatan statuta dan pendekatan historis. Hasil penelitian } \\
\text { menunjukan definisi, batasan serta yurisdiksi ICC atas kejahatan agresi }\end{array}$ \\
\hline
\end{tabular}




\section{A. PENDAHULUAN}

Negara dalam kapasitasnya sebagai salah satu subjek hukum internasional memiliki hak dan kewajiban yang berkaitan dengan kedaulatan. Negara bebas dan merdeka untuk menjalankan hak kedaulatannya secara penuh tetapi juga berkewajiban memperhatikan batas-batasnya untuk tidak menjalankan kedaulatannya di wilayah negara lain. ${ }^{1}$ Pada masa tahun 1920-an telah tampak adanya upaya pembentukan Mahkamah Pidana Internasional terutama setelah terbentuknya Liga Bangsa-Bangsa (LBB). Upaya tersebut berasal dari sejumlah ahli hukum terkemuka seperti Vespasien Pella, Donnedieu de Vebres, Quintiliano Saldana, Megalos Ciloyanni dan Rafaele Garofalo. Dukungan atas upaya tersebut juga berdatangan dari perkumpulan masyarakat internasional seperti, The Internasional Law Association, The American Society of Internasional Law, dan The International Parliamentary Union. ${ }^{2}$

Upaya-upaya dari ahli hukum dan beberapa perkumpulan masyarakat internasional tidak hanya menjadi sebuah harapan tetapi dapat direalisasikan. Hal tersebut dapat dilihat dalam kurun waktu 50 tahun terakhir telah dibentuk empat mahkamah internasional yang bersifat ad hoc, yang terdiri dari: ${ }^{3}$ Pertama, pembentukan mahkamah kejahatan internasional pasca Perang Dunia Kedua usai, yaitu International Military Tribunal (IMT) atau dikenal sebagai Nuremberg Tribunal pada tahun 1945 dan International Military Tribunal for the Far East (IMTFE) pada 1946; Kedua, pembentukan mahkamah kejahatan internasional setelah perang dingin, yaitu International Criminal Tribunal for Former Yugoslavia (ICTY) dan International Criminal Tribunal for Rwanda (ICTR).

Empat mahkamah ad hoc yang dibentuk tersebut memberikan dasar yang positif dan negatif bagi terbentuknya Mahkamah Pidana Internasional yang bersifat permanen (Internasional Criminal Court, ICC). Dasar-dasar tersebut seperti ditemukannya definisi kejahatan tertentu dan kritik-kritik dalam pelaksanaan yurisdiksi oleh mahkamah ad hoc. IMT dikritik sebab tidak mengadili seluruh pelaku kejahatan yang merupakan pimpinan NAZI pada Perang Dunia II, bahkan kebebasan dari hukuman yang mestinya diterima oleh mereka tersebut nampak merupakan suatu balas jasa atas apa yang telah mereka lakukan sehingga mereka mendapatkan pengampunan atas kejahatan mereka tersebut. ${ }^{4}$ Di samping itu, IMT juga dikritik sebagai Mahkamah bagi pemenang perang (victor's justice) karena semua jaksa dan hakim berasal dari sekutu, bukan dari negara netral. Semua terdakwa dan pembelanya berasal dari Jerman, dan mereka mendapat fasilitas yang sangat terbatas dalam mempersiapkan kasus-kasus mereka serta mendapatkan pemberitahuan mengenai buktibukti penuntutan. ${ }^{5}$ Namun demikian, IMT sangat berarti bagi penegakkan hak asasi manusia

1 Nisa, Candra Ulfatun dan Disemadi, Hari Sutra. (2020). "Yurisdiksi Kriminal Terhadap Black Flight Di Ruang Udara Wilayah Indonesia”, SASI, 26 (3): 365-379. DOI: https://doi.org/10.47268/sasi.v26i3.289, h. 365.

2 Atmasasmita, R. (2006). Pengantar Hukum Pidana Internasional. Bandung: Refika Aditama, h. 4

3 Muladi. (2011). Statuta Roma 1998 Tentang Mahkamah Pidana Internasional Dalam Kerangka Hukum Pidana Internasional dan Implikasinya Terhadap Kerangka Hukum Pidana Nasional. Bandung: Alumni, h. 25

${ }^{4}$ Robertson, G. (2002). Kejahatan Terhadap Kemanusiaan: Perjuangan Untuk Mewujudkan Keadilan Global. Jakarta: Komisi Hak Asasi Manusia, h. 252

5 Ibid., h. 271 
internasional karena telah meletakkan prinsip-prinsip dasar pertanggungjawaban pidana secara individu (yang tertuang dalam Piagam Nuremberg/Nuremberg Principle). Selain itu, definisi kejahatan terhadap kemanusiaan yang diatur dalam Pasal 6(c) Piagam Nuremberg, belum pernah ditemukan dalam Konvensi-Konvensi sebelumnya. Mahkamah ini juga secara tegas menolak prinsip 'impunitas kedaulatan negara' seperti yang tertuang dalam pasal 7 Piagam Nuremberg. ${ }^{6}$

Tidak berbeda jauh dengan IMT, IMTF juga dikritik sebagai mahkamah victor's justice sebab Jepang tidak diizinkan untuk membawa AS ke hadapan Mahkamah Tokyo atas tindakan pemboman Hiroshima dan Nagasaki yang dilakukan AS, dan Jepang juga tidak diizinkan untuk mengadili Uni Soviet atas pelanggarannya terhadap perjanjian kenetralan tanggal 13 April 1941. ${ }^{7}$ Selain itu praktik impunitas juga sangat jelas terjadi dalam Mahkamah ini ketika Amerika Serikat memutuskan untuk tidak membawa Kaisar Hirohito ke meja pengadilan, tapi justru melanggengkan kedudukannya dalam Kekaisaran Jepang. ${ }^{8}$

ICTY dikritik sebab banyak kalangan yang menganggap bahwa mahkamah ini hanyalah kebetulan belaka mengingat berbagai kegagalan diplomasi dan sanksi serta penolakan PBB untuk mengorbankan tentara keamanannya melalui intervensi bersenjata membuat mahkamah terhadap penjahat perang sebagai alat satu-satunya untuk menyelamatkan muka PBB. ${ }^{9}$ Mahkamah ini juga dikritik mempraktikkan selective justice (keadilan yang selektif) sebab hanya mendirikan Mahkamah untuk mengadili kejahatan yang dilakukan di negaranegara tertentu, serta Mahkamah ini jelas berdasarkan pada anti-Serbian bias. ${ }^{10}$ Selain itu, Mahkamah ini juga tidak mengadili angkatan bersenjata NATO yang ikut melakukan pemboman di Negara bekas Yugoslavia. Padahal, sangatlah jelas serangan udara yang dilakukan NATO terhadap Kosovo seharusnya menuntut pertanggungjawaban para pemimpin NATO atas pilihan target pemboman yang mereka lakukan karena jelas merupakan pelanggaran terhadap hukum perang. ${ }^{11}$

Sama halnya dengan ICTY, kritikan bahwa Mahkamah mempraktikkan selective justice juga ditujukan kepada PBB ketika Dewan Keamanannya mendirikan ICTR. ${ }^{12}$ Banyak kalangan menilai, ICTY dan ICTR ini hanyalah Mahkamah Internasional yang didirikan dengan alasan yang sangat politis, dan berdasarkan prinsip yang abstrak dan tidak jelas dan itu jauh lebih kejam bila dibandingkan dengan segala jenis kejahatan yang dituduhkan kepada Milosevic. ${ }^{13}$

Kritikan-kritikan yang disematkan ke seluruh Mahkamah ad hoc tersebut merupakan salah satu sebab yang mendorong harapan untuk segera dibentuknya Mahkamah Pidana Internasional yang bersifat permanen dan tentunya untuk dapat meminimalisir praktikpraktik seperti selective justice. Pada akhirnya, harapan tersebut tercapai di mana pada tanggal 17 Juli 1998 dengan 120 Negara dalam United Nations Diplomatic Conference on Plenipotentiaries on the Establishment of an International Criminal Court sepakat untuk mengesahkan Statuta Roma yang merupakan statuta dari ICC.

Transnasional atau lintas negara mengakibatkan timbulnya permasalahan hukum suatu

\footnotetext{
${ }^{6}$ Lembaga Studi dan Advokasi Masyarakat. (2015). Kajian Ratifikasi Statuta Roma 1998. Retrieved from https://advokasi.elsam.or.id/assets/2015/09/00000000_Kajian_Ratifikasi-statuta-roma1998_ELSAM.pdf, h. 5

7 Ibid.

8 Robertson, G. Op. Cit., h. 252

9 Ibid., h. 352-353

${ }^{10}$ Cassese, A. (2003). Internasional Criminal Law. Oxford: Oxford University Press, h. 337

11 Lembaga Studi dan Advokasi Masyarakat. Op. Cit., h. 6-7

12 Kittichaisaree, K. (2001). International Criminal Law. Oxford: Oxford University Press, h. 24

13 Lembaga Studi dan Advokasi Masyarakat. Op. Cit., h. 7
} 
negara dengan negara lain yang memerlukan penanganan melalui hubungan baik berdasarkan hukum di masing-masing negara ${ }^{14}$. Pembentukan ICC merupakan perwujudan dari international criminal policy atau suatu usaha-usaha rasional dari negara-negara di dunia untuk secara bersama-sama menanggulangi four core crimes yang merupakan pelanggaran terhadap delicto jus gentium. Policy tersebut diperlukan sebab pelanggaranpelanggaran tersebut memiliki unsur-unsur (elements), yaitu: pertama, direct threat to world peace and security (ancaman secara langsung atas perdamaian dan keamanan di dunia); kedua, indirect threat to world peace and security (ancaman secara tidak langsung terhadap perdamaian dan keamanan di dunia); ketiga, "shocking" to the conscience of humanity (menggoyahkan perasaan kemanusiaan); keempat, conduct affecting more than one State (tindakan yang memiliki dampak terhadap lebih dari satu Negara); kelima, conduct including or affecting citizens of more than one state (tindakan yang melibatkan atau memberikan dampak terhadap warga Negara dari lebih satu Negara); dan keenam, means and methods transcend national boundaries (sarana dan prasarana serta metode-metode yang dipergunakan melampaui batas-batas teritorial suatu Negara). ${ }^{15}$ Four core crimes sendiri merupakan empat tindak pidana internasional yang terdiri dari kejahatan genosida (the crimes of genocide), kejahatan terhadap kemanusiaan (crimes against humanity), kejahatan perang (war crimes) dan kejahatan agresi (the crimes of aggression). ${ }^{16}$ Keempat kejahatan tersebut sering pula disebut sebagai international crimes stricto sensu.

Dalam usaha pembentukan ICC, konsep kejahatan agresi merupakan salah satu hal yang dibahas dalam waktu yang sangat panjang. Hal ini dapat dilihat hingga berlakunya Statuta Roma, di dalamnya tidak juga ditemukan definisi agresi. Keterlambatan dalam menuangkan definisi kejahatan agresi telah menyebabkan beberapa masalah. Pertama, tidak seperti kejahatan internasional substantif lainnya, agresi merupakan suatu kejahatan 'kepemimpinan' dan tentu saja harus ditentukan sebagai titik awalnya bahwa negara tersebut, di mana terdakwa menjadi 'pemimpin' dalam kapasitas tertentu, telah melakukan agresi. Proposisi ini berbeda sepenuhnya dari pendirian tentang tanggung jawab individu atas genosida, kejahatan perang atau kejahatan terhadap kemanusiaan. Juga tidak jelas perbedaan apa yang mungkin ada di antara tindakan agresi negara dan kejahatan agresi individu.

Kedua, Pasal 5 (2) Statuta Roma menyatakan bahwa syarat pelaksanaan yurisdiksi Pengadilan harus selaras dengan ketentuan relevan dalam Charter of the United Nations (Piagam Perserikatan Bangsa-Bangsa/Piagam PBB). Seperti diketahui, Dewan Keamanan (DK PBB) memiliki kompetensi berdasarkan Bab VII Piagam PBB untuk menentukan apakah suatu tindakan agresi telah terjadi dan berpendapat bahwa perlu ada penentuan oleh Dewan sebelum pengadilan dapat melaksanakan yurisdiksi terkait tanggung jawab individu atas agresi. Hal ini telah menjadi bahan perdebatan. Namun, pertanyaan tentang hubungan antara kompetensi masing-masing Dewan dan Pengadilan tidak terjawab. ${ }^{17}$

Benjamin B. Ferenczs ${ }^{18}$ melihat ada empat skenario yang dihadapi oleh masyarakat internasional akibat tidak dimasukkannya definisi dan batasan-batasan dari kejahatan agresi pada Statuta Roma. Pertama, melihat tidak adanya kesepakatan mengenai kejahatan agresi

14 Hartono, Bambang dan Hapsari, Recca Ayu. (2019). "Mutual Legal Assistance Pada pemberantasan Cyber Crime Lintas Yurisdiksi di Indonesia”. SASI, 25 (1): 59-71. DOI: https://doi.org/10.47268/sasi.v25i1.136, h. 67.

15 Bassiouni, C. (1986). Internasional Criminal Law, Vol. I Crimes. New York: Transnational Publishers.

16 Gunakaya, W. (2013). "Peranan dan Prospek "Internasional Criminal Court" Sebagai International Criminal Policy Dalam Menanggulangi "International Crimes". Jurnal Wawasan Hukum, 29 (2), h. 790

17 Shaw, M. N. (2008). Hukum Internasional. Cambridge: Cambridge University Press, h. 400

18 Suarda, I. G. W. (2012). Hukum Pidana Internasional Sebuah Pengantar. Bandung: Citra Aditya Bakti, h. 210 
atau aturan dari Dewan Keamanan PBB maka ICC tidak akan memiliki yurisdiksi atas kejahatan agresi. Kedua, dengan tidak adanya yurisdiksi ICC, para agresor masih tetap dapat dituntut oleh si pemenang yang dapat mengalahkan si agresor atau oleh suatu pemerintahan yang baru. Ketiga, suatu Mahkamah Ad-Hoc masih dapat dibentuk oleh Dewan Keamanan PBB kepada agresor. Terakhir, ICC dapat menjalankan yurisdiksinya atas kejahatan agresi berdasarkan Statuta Roma. Dengan demikian, apabila melihat skenario terakhir, tetap ada harapan yang realistis untuk memasukkan definisi dan batasan-batasan dari kejahatan agresi sehingga dapat dijangkau oleh yurisdiksi ICC.

Melihat realita pengaturan kejahatan agresi pada Statuta Roma tersebut, tidak mengherankan apabila tindak kejahatan agresi yang terjadi di dunia pasca perang dunia dua atau lebih tepatnya dalam kurun waktu dimulainya proxy war/cold war tidak diproses oleh ICC. Seperti agresi militer yang dilakukan oleh Amerika Serikat (AS) ke Irak dengan dalih untuk menangkap Sadam Hussein, Presiden Irak, yang dianggap sebagai penjahat perang dan anggapan adanya indikasi Irak menyimpan senjata pemusnah masal. ${ }^{19}$ Agresi militer AS terhadap Irak tersebut terjadi pada tahun 2003 di mana Statuta Roma masih belum memasukkan definisi dan batasan-batasan yang jelas terkait kejahatan agresi sehingga menjadikan pimpinan AS kala itu tidak diseret ke ICC atas dasar dugaan telah melakukan kejahatan agresi di Irak.

Sisi kelam dari realita ini adalah apabila keadaan di mana kejahatan agresi akan tetap dibiarkan berlangsung tanpa ada sanksi yang tegas kepada individu yang bertanggung jawab atas agresi tersebut, maka dapat dikatakan usaha-usaha rasional dari negara-negara di dunia untuk secara bersama-sama menanggulangi four core crimes atau international criminal stricto sensu tidak sepenuhnya dapat dilakukan. Dan terlebih lagi bahwa dengan keadaan demikian berati pelanggaran terhadap delicto jus gentium terus terjadi sekalipun ICC telah dibentuk. Sementara sisi terangnya, perlu diketahui, bahwa pada tahun 2010, pembahasan mengenai definisi dan batasan-batasan terkait kejahatan agresi yang dituangkan dalam Kampala Amendments telah diadopsi ke dalam Statuta Roma. Untuk itu, tulisan ini akan membahas tentang bagaimana definisi, batasan-batasan serta penegakkan Yurisdiksi ICC atas kejahatan agresi pasca adopsi Kampala Amendments ke dalam Statuta Roma dilakukan

\section{B. METODE PENELITIAN}

Artikel ini disusun dengan menggunakan jenis penelitian hukum normatif atau disebut juga sebagai penelitian kepustakaan atau studi dokumen. Adapun metode pendekatan yang digunakan adalah pendekatan statuta (statute approach) dan pendekatan historis (historical approach). Pendekatan historis digunakan untuk melihat perkembangan kelembagaan ICC beserta aturan-aturan terkait dengan kejahatan agresi. Adapun pendekatan pendekatan statuta digunakan untuk melihat pengaturan aktual kejahatan agresi. Selanjutnya, pengumulan bahan hukum dalam artikel ini dilkukan dengan studi kepustakaan. Bahan hukum tersebut kemudian dianalisis secara yuridis kualitatif.

\section{PEMBAHASAN}

\section{Yurisdiksi Internasional Criminal Court}

Pada dasarnya Yurisdiksi ICC terbagi menjadi empat yang terdiri dari teritorial jursidiction (ratione loci), material jursidiction (rationae materiae), temporal jurisdiction

19 Nurhidayatuloh. (2011). "Kejahatan Agresi Dalam Tatanan Hukum Internasional Modern Sebagai Peremptory Norm”. QISTI: Jurnal Ilmiah Ilmu Hukum, 5 (2), h. 120 
(ratione temporis), dan personal jursdiciton (ratiionae personae). Territorial jurisdiction berarti yurisdiksi ICC hanya berlaku dalam wilayah negara pihak, yurisdiksi juga diperluas bagi kapal atau pesawat terbang yang terdaftar di Negara pihak, dan dalam wilayah bukan Negara Pihak yang mengakui yurisdiksi ICC berdasarkan deklarasi Ad Hoc. ${ }^{20}$ Material jurisdiction berarti kejahatan yang menjadi yurisdiksi ICC terdiri dari kejahatan terhadap kemanusiaan, kejahatan perang, genosida dan kejahatan agresi. ${ }^{21}$ Temporal jurisdiction berarti ICC baru memiliki yurisdiksi terhadap kejahatan yang diatur dalam Statuta setelah Statuta Roma berlaku yakni 1 Juli 2002. ${ }^{22}$ Personal jurisdiction berarti ICC memiliki yurisdiksi atas orang (natural person), di mana pelaku kejahatan dalam yurisdiksi ICC harus mempertanggungjawabkan perbuatannya secara individu (individual criminal responsibility), termasuk pejabat pemerintahan, komandan baik militer maupun sipil. ${ }^{23}$

Terkait dengan material jurisdiction, Pasal 5 (1) Statuta Roma telah menegaskan, yurisdiksi pengadilan pidana internasional terbatas pada empat bentuk international crimes, yaitu: (1) The crime of genocide (genosida); (2) Crimes against humanity (kejahatan terhadap kemanusiaan); (3) War crimes (kejahatan perang); dan (4) The crimes of aggresion (kejahatan agresi). Keempat bentuk kejahatan tersebut merupakan bentuk-bentuk international crimes dalam pengertian stricto sensu. Sebagaimana telah dikemukakan sebelumnya, international crimes stricto sensu adalah kejahatan internasional dalam arti sempit, yaitu kejahatan-kejahatan yang menjadi yurisdiksi dari pengadilan pidana internasional. $^{24}$

Dari keempat international criminal stricto sensu, sejak berlaku efektifnya Statuta Roma, hanya tiga di antaranya yang sudah terdefinisi secara jelas dalam Pasal 6, 7 dan 8 Statuta Roma, yaitu genosida, kejahatan terhadap kemanusiaan, dan kejahatan perang. Kejahatan agresi tidak terdefinisi secara jelas di dalam Statuta Roma.

Kejahatan agresi dirujuk dalam Pasal 5 Statuta ICC, tetapi tidak dalam instrumen lain semacamnya. Memang, Pasal 5 (2) mengatur bahwa pengadilan tidak dapat menjalankan yurisdiksi atas kejahatan agresi sampai diadopsi sebuah ketentuan yang mendefinisikan kejahatan tersebut dan menetapkan kondisi di mana Pengadilan bisa menjalankan yurisdiksi mengenainya.

Kejahatan yang menjadi yurisdiksi ICC pertama adalah genosida, yaitu sebagai salah satu atau lebih dari beberapa perbuatan yang dilakukan dengan maksud untuk menghancurkan seluruh atau sebagian kelompok bangsa, etnis, ras atau agama seperti: ${ }^{25}$

1) Membunuh anggota kelompok

2) Menyebabkan penderitaan fisik atau mental yang berat terhadap anggota kelompok

3) Sengaja menciptakan kondisi kehidupan kelompok yang akan mengakibatkan kemusnahan secara fisik baik seluruhnya atau sebagian.

4) Memaksa tindakan-tindakan yang bertujuan mencegah kelahiran di dalam suatu kelompok

5) Memindahkan secara paksa anak-anak dari suatu kelompok ke kelompok lainnya.

Selanjutnya statuta menjelaskan definisi tentang kejahatan terhadap kemanusiaan yaitu salah satu atau lebih dari beberapa perbuatan yang dilakukan dengan sengaja sebagai bagian dari serangan yang sistematis dan meluas yang langsung ditujukan terhadap pendudukan

\footnotetext{
20 Article 12 Rome Statute

21 Article 5-8 Rome Statute

22 Article 11 Rome Statute

23 Article 25 Rome Statute

24 Suarda, I. G. W. (2012). Op. Cit., h. 163

25 Article 6 Rome Statute
} 
sipil, seperti: ${ }^{26}$

1) Pembunuhan

2) Pembasmian

3) Pembudakan

4) Deportasi atau pemindahan pendudukan secara paksa

5) Pengurangan atau pencabutan kemerdekaan fisik secara sewenang-wenang dan melanggar aturan-aturan dasar hukum internasional

6) Penyiksaan

7) Pemerkosaan, perbudakan seksual, pelacuran secara paksa, kehamilan secara paksa, sterilisasi secara paksa atau berbagai bentuk kekerasan seksual lainnya

8) Penindasan terhadap suatu kelompok yang dikenal atau terhadap suatu kelompok politik, ras, bangsa, etnis, kebudayaan, agama, jender atau jenis kelamin, sebagaimana dijelaskan dalam ayat (3) atau kelompok-kelompok lainnya, yang secara unibversal tidak diperbolehkan dalam hukum internasional sehubungan perbuatan yang diatur dalam ayat ini atau tindak pidana dalam yurisdiksi mahkamah

9) Penghilangan orang secara paksa

10) Tindak pidana rasial (apartheid)

11) Perbuatan tidak manusiawi lainnya yang serupa, yang dengan sengaja mengakibatkan penderitaan yang berat, luka serius terhadap tubuh, mental atau kesehatan fisik seseorang.

Selanjutnya, Tindak pidana internasional yang termasuk dalam kejahatan luar biasa adalah kejahatan perang di mana merupakan tindakan yang dilakukan sebagai bagian dari rencana atau kebijakan atau bagian dari skala besar perintah untuk melakukan tindakan pidana tersebut. Tindakan pidana ini termasuk: ${ }^{27}$

1) Pelanggaran-pelanggaran berat terhadap konvensi-konvensi Jeneva 12 Agustus 1949 yaitu perbuatan-perbuatan terhadap orang atau harta benda yang dilindungi oleh ketentuan-ketentuan dari konvensi yang relevan

2) Pelanggaran-pelanggaran serius lainnya terhadap hukum dan kebiasaan yang berlaku dalam konflik bersenjata internasional dalam kerangka hukum internasional

3) Pelanggaran-pelanggaran serius terhadap Pasal 13 yang berlaku bagi keempat konvensi Jeneva dalam sengketa yang bukan bersifat internasional.

\section{Perkembangan Definisi Kejahatan Agresi}

Pengertian agresi memang sangatlah krusial dan kompleks. Secara historis, agresi sudah berulang kali dirumuskan definisinya secara tepat namun belum juga terlaksana. Tercatat sejak League of Nations (Liga Bangsa-Bangsa/LBB) lahir, agresi sudah menjadi perhatian utama. Hal ini diketahui karena terdapat pula agresi dalam Kovenan LBB, sebagaimana berikut: ${ }^{28}$

"The Members of the League undertake to respect and preserve as against external aggression the territorial integrity and existing political independence of all Members of the League. In case of any such aggression or in case of any threat or danger of such aggression the Council shall advise upon the means by which this obligation shall be fulfilled". (Anggota LBB berusaha untuk menghormati dan melindungi timbulnya agresi dari luar, keutuhan wilayah dan kemerdekaan politik dari semua anggota LBB.

26 Article 7 Rome Statute

27 Article 8 Rome Statute

28 Article 10 The Covenant of the League of Nations 
Jika dalam hal agresi semacam itu terjadi dan dalam hal terjadinya ancaman bahaya dari agresi tersebut, maka Dewan LBB akan menyarankan dengan cara-cara di mana kewajiban itu dapat dicapai.)

Namun demikian, definisi agresi dalam kovenan tersebut masih dianggap sumir. Oleh karena itu dalam perkembangannya, pengertian tentang agresi ini dibahas pula dalam Perjanjian Briand dan Kallog tahun 1928 atau yang sering disebut dengan Paris Pact. Akan tetapi, dalam Paris Pact ini Amerika Serikat menganggap pemberian definisi ini tidak praktis karena tidak dapat memasukkan semua elemen dan memungkinkan bagi agresor untuk menggunakan definisi kepentingannya sendiri. Dari pakta ini terlihat bahwa penolakan terhadap perang sangatlah penting untuk dilakukan. Pakta tersebut menegaskan bahwa: ${ }^{29}$

"...their respective peoples that they condemn recourse to war for the solution of international controversies, and renounce it, as an instrument of national policy in their relations with one another". (.... Jalan lain menuju peperangan bagi penyelesaian perselisihan-perselisihan internasional dan penolakan hal itu sebagai instrumen dari kebijakan nasional dalam hubungannya dengan yang lain merupakan tindakan yang dikutuk.)

Definisi agresi selanjutnya terdapat dalam 'Konvensi tentang Definisi Agresi' yang ditandatangani pada tahun 1933 di London yang memberikan definisi agresi yaitu: ${ }^{30}$

(1) Pernyataan perang terhadap negara lain.

(2) Melakukan invasi dengan kekuatan senjata bahkan sekalipun tanpa adanya pernyataan perang terhadap wilayah suatu negara

(3) Suatu serangan melalui darat, laut dan udara terhadap wilayah, kapal laut dan kapal terbang negara lain.

(4) Melakukan blokade laut di pantai atau pelabuhan negara

(5) Pemberian bantuan terhadap gerombolan senjata yang dibentuk di wilayah negara lain.

Pada 26 Juni 1945 di San Fransisco di tandatangani Piagam PBB. Di dalamnya, "agresi”" disebutkan pada Bab VII yang menyatakan bukan saja agresi tetapi adanya pelanggaran dan ancaman terhadap perdamaian. Namun, Bab VII sebenarnya berbicara tentang sanksi terhadap suatu negara yang melakukan agresi (agresor) dan sebelum mengambil tindakan sesuai dengan Pasal 39-51 yang termuat dalam Bab VII tersebut. Dewan Keamanan pertamatama haruslah memutuskan bahwa dalam suatu situasi dan konflik memang terjadi ancaman perdamaian, pelanggaran perdamaian atau tindak agresi. Sehubungan dengan hal tersebut, penting sekali bagi Dewan Keamanan untuk mengetahui arti dan definisi dari agresi. ${ }^{31}$ Berdasarkan Bab VII Piagam PBB, Dewan Keamanan memiliki kompetensi untuk menentukan apakah suatu tindakan agresi telah terjadi dan berpendapat bahwa perlu ada penentuan oleh Dewan sebelum pengadilan dapat melaksanakan yurisdiksi terkait tanggung jawab individu atas agresi. Hal ini telah menjadi bahan perdebatan. Namun, pertanyaan tentang hubungan antara kompetensi masing-masing Dewan dan Pengadilan tidak terjawab. ${ }^{32}$

Selanjutnya, dalam the London Agreement tanggal 8 Agustus 1945, yang menjadi dasar terbentuknya IMT, pada Paragraph a Article 6 atas larangan agresi yang menimbulkan

29 Article I Briand and Kellog Pact 1928

30 Article II Convention on the Defenition of Aggression, London, 1933

31 Suryokusumo, S. (2005). “Agresi Dalam Perspektif Hukum Internasional”. Jurnal Hukum Internasional, 3 (1), h. 36

32 Shaw, M. N. (2008). Op. Cit., h. 400

547 | S A S I Vol. $26 \mathrm{No.4,}$ Oktober - Desember 2020 
pertanggung jawaban individual, berbunyi: ${ }^{33}$

"Crimes against Peace: namely, planning, preparation, initiation or waging of wars of aggression, or a war in violation of international treaties, agreements or assurances, or participation in a common plan or conspiracy for the accomplishment of any of the foregoing" (Kejahatan terhadap Perdamaian: yaitu, perencanaan, persiapan, inisiasi atau melancarkan perang agresi, atau perang yang melanggar perjanjian kesepakatan atau jaminan internasional, atau partisipasi dalam rencana umum atau konspirasi untuk pemenuhan dari salah satu di atas).

Setelah perjuangan selama 21 tahun oleh para ahli hukum dan ahli politik, akhirnya definisi agresi ini mulai menemukan titik terang. Berawal dari komite khusus yang dibentuk PBB untuk merumuskannya, tercapailah kesepakatan definisi agresi yang terdiri dari 8 Pasal di mana definisi ini pada akhirnya disetujui dengan aklamasi oleh Majelis Umum PBB dalam sidangnya tertanggal 14 Desember 1974 dan dituangkan dalam Resolusi Majelis Umum 3314 (XXIX).

Pada Pasal 1 menyebutkan bahwasanya "agresi adalah penggunaan pasukan bersenjata oleh suatu negara terhadap kedaulatan, keutuhan wilayah atau kemerdekaan politik dari negara lain, atau dengan cara-cara lain apa pun yang bertentangan dengan Piagam PBB.". Dalam agresi tidak mempersoalkan istilah negara dalam pengakuan atau apakah negara itu merupakan anggota PBB atau tidak. Syarat negara yang tercantum dalam Konvensi Montevideo 1933 yakni populasi penduduk, wilayah, pemerintahan menjadi atribut pokok atau esensial attribute dalam negara. Namun persoalan selebihnya yaitu kewenangan berhubungan dengan negara lain.

Pasal 2 berbicara mengenai "penggunaan pasukan bersenjata yang pertama dilakukan oleh suatu negara, tidak sesuai dengan piagam, akan merupakan bukti prime factie dari suatu tindak agresi, meskipun Dewan Keamanan menurut Piagam dapat menentukan bahwa suatu tindak agresi yang dilakukan tidaklah dibenarkan." Kemudian Pasal 3 membahas mengenai "setiap tindakan yang tersebut di bawah ini tanpa memandang adanya pernyataan perang sesuai Pasal 2 di atas dianggap sebagai tindakan agresi:

a) Invasi atau serangan yang dilakukan oleh pasukan bersenjata dari suatu negara ke wilayah negara lainnya atau sebagian dari wilayah itu.

b) Pemboman oleh pasukan bersenjata dari suatu negara apa pun oleh suatu negara terhadap wilayah negara lain

c) Blokade di pelabuhan atau negara pantai dari suatu negara oleh pasukan bersenjata dari negara lain

d) Suatu serangan oleh pasukan bersenjata dari suatu negara dengan angkatan darat, laut dan udara, marine di lapangan terbang negara lain

e) Penggunaan pasukan bersenjata dari suatu negara yang berada di wilayah negara lain.

f) Tindakan dari suatu negara untuk mengizinkan di wilayahnya atas perintah negara lain, digunakan oleh negara lain untuk melakukan suatu tindakan agresi terhadap negara ketiga.

g) Pengiriman oleh, atas nama negara suatu negara, kelompok atau gerombolan orang bersenjata, pasukan sewaan yang melakukan tindak-tindakan dengan kekuatan senjata terhadap negara lain dengan suatu gravitasi agar dapat memperkuat

33 Ferencz, B. B. (2007). "Enabling the International Criminal Court to Punish Aggression”. Washington University Global Studies Law Review, 6 (5), h. 551 
tindakan-tindakan seperti tersebut di atas atau keterlibatannya secara substansial di dalamnya.

Pasal 4 menyatakan "tindakan-tindakan yang telah diuraikan di atas belum berarti mencakup keseluruhannya dan DK-PBB bisa saja menentukan bahwa tindakan-tindakan lainnya sesuai dengan ketentuan Piagam PBB." Dan Pasal 5 lebih lanjut menyatakan "tidak ada pertimbangan mengenai sifat apa pun baik politik, ekonomi, militer atau lainnya yang dapat dijadikan sebagai alasan pembenar mengenai agresi. Agresi merupakan kejahatan terhadap perdamaian dunia. Agresi menyebabkan tanggung jawab internasional dan tidak ada perolehan wilayah atau keuntungan khusus sebagai hasil dari agresi tersebut akan diakui secara sah".

Pasal 6 menyebutkan "tidak ada yang dapat ditafsirkan di dalam definisi ini bagaimanapun juga untuk memperbesar atau mengurangi lingkup piagam termasuk ketentuan-ketentuannya mengenai kasus-kasus di mana penggunaan kekerasan itu sah". Sedang Pasal 7 "tidak ada dalam definisi ini, khususnya Pasal 3 bagaimanapun juga yang dapat merugikan hak penentuan nasib sendiri, kebebasan, kemerdekaan, sebagaimana tersebut di dalam Piagam, menghilangkan hak bangsa-bangsa tersebut dengan paksa sebagaimana tersebut juga dalam Deklarasi tentang Prinsip-prinsip Hukum Internasional yang mengatur hubungan bersahabat dan kerjasama antar Bangsa-Bangsa sesuai dengan Piagam PBB...".

Pasal terakhir Resolusi Majelis Umum PBB ini menyatakan bahwa "Dalam penafsiran dan penerapan ketentuan-ketentuan tersebut adalah berkaitan dan setiap ketentuan harus ditafsirkan dalam konteks ketentuan lainnya."

Sekalipun pada Akhirnya Majelis Umum PBB (Resolusi MU-PBB) melalui Resolusi menegaskan definisi dari agresi. Namun demikian, banyak pihak menyayangkan mengapa definisi ini hanya dikeluarkan melalui Resolusi MU-PBB sehingga kekuatan hukumnya sangat disangsikan karena resolusi itu bersifat externa corporis, suatu keputusan yang hanya bersifat rekomendasi dan kurang mempunyai kekuatan hukum yang mengikat. Keadaan inilah yang kemudian mendorong untuk dilakukan amandemen terhadap Statuta Roma dengan lebih mengkhususkan pada penegasan mengenai agresi di dalam Statuta Roma.

Akhirnya sejak dibahas pada bulan Mei-Juni 2010 di Review Conference of Rome Statute yang berlangsung di Kampala, Uganda, tepat pada tanggal 10-11 Juni 2010, Kampala Amendments disepakati dan diadopsi. Di dalam amandemen tersebut, diatur tentang definisi, kondisi aktivasi dan yurisdiksi ICC atas kejahatan agresi. Di dalam Statuta Roma di tambahkan Pasal 8 bis yang memberikan definisi untuk kejahatan agresi sebagai: "Perencanaan, persiapan, Inisiasi atau pelaksanaan, oleh seseorang dalam posisi secara efektif untuk menjalankan kendali atas atau mengarahkan tindakan politik atau militer dari suatu Negara, dari tindakan agresi yang, dengan karakter, gravitasi dan skala, merupakan pelanggaran nyata dari Piagam PBB. ". Selain itu ditambahkan pula dalam Statuta Roma Pasal 15 bis dan 15 ter terkait Pelaksanaan Yurisdiksi atas Kejahatan Agresi. Dengan diadopsinya Kampala Amandments, maka secara tegas definisi agresi tidak lagi hanya diatur dalam resolusi MU-PBB yang bersifat externa corporis akan tetapi sudah dituangkan dalam Statuta Roma yang merupakan dasar bagi ICC untuk menegakkan yurisdiksinya

\section{Yurisdiksi Internasional Criminal Court atas Kejahatan Agresi Berdasarkan Kampala Amendments}

Pada rentang waktu 31 Mei sampai dengan 11 Juni 2010 di Kampala, Uganda, telah diselenggarakan the Review Conference of the Rome Statute. Tepat pada 11 Juni 2010 para 
Negara Pihak mengadopsi amandemen atas kejahatan agresi dalam statuta roma. Amandemen ini kemudian disebut sebagai Kampala Amendment.

Terdapat beberapa hal yang berubah dalam substansi Statuta Roma pasca Kampala Amandment diadopsi. Perubahan-perubahan tersebut yaitu:

1) Pasal 5 Ayat 2 dihapus

2) Pasal 8 bis dimasukkan setelah Pasal 8 dan Pasal 15 bis serta Pasal 15 ter dimasukkan setelah Pasal 15

3) Ayat 3 bis dimasukkan dalam Pasal 25 setelah ayat 3

4) Perubahan Pasal 9 ayat 1 dan Pasal 20 Ayat 3

Pasal 8 bis berisi definisi dari kejahatan agresi dan penegasan untuk tidak melanggar ketentuan sebagaimana yang tertuang dalam Resolusi MU-PBB 3314 (XXIX), 14 Desember 1974. Secara lengkap Pasal 8 bis berbunyi sebagaimana berikut: ${ }^{34}$

1) For the purpose of this Statute, "crime of aggression" means the planning, preparation, initiation or execution, by a person in a position effectively to exercise control over or to direct the political or military action of a State, of an act of aggression which, by its character, gravity and scale, constitutes a manifest violation of the Charter of the United Nations. (Untuk tujuan Statuta ini, "kejahatan agresi" berarti perencanaan, persiapan, inisiasi atau eksekusi, oleh seseorang yang berada dalam posisi yang efektif untuk melakukan kontrol atas atau mengarahkan tindakan politik atau militer suatu Negara, suatu tindakan agresi yang, berdasarkan karakternya, gravitasi dan skalanya, merupakan pelanggaran nyata Piagam PBB.)

2) For the purpose of paragraph 1, "act of aggression" means the use of armed force by a State against the sovereignty, territorial integrity or political independence of another State, or in any other manner inconsistent with the Charter of the United Nations. Any of the following acts, regardless of a declaration of war, shall, in accordance with United Nations General Assembly resolution 3314 (XXIX) of 14 December 1974 .... (Untuk tujuan ayat 1, "tindakan agresi" berarti penggunaan angkatan bersenjata oleh suatu Negara terhadap kedaulatan, integritas wilayah atau kemerdekaan politik dari Negara lain, atau dengan cara lain apa pun yang tidak sesuai dengan Piagam Perserikatan Bangsa-Bangsa. Setiap tindakan berikut, terlepas dari deklarasi perang, harus, sesuai dengan resolusi Majelis Umum PBB 3314 (XXIX) tanggal 14 Desember 1974 ...)

Selanjutnya, di dalam Pasal 15 bis mengatur tentang pelaksanaan yurisdiksi ICC atas kejahatan agresi khususnya yang diteruskan oleh suatu Negara Pihak kepada Penuntut Umum dan yang diprakarsai sendiri oleh Penuntut Umum (proprio motu).

Berdasarkan Pasal 15 bis yurisdiksi ICC atas kejahatan agresi berlaku mulai 1 Januari 2017 dan mulai berlaku bagi tiga puluh Negara Pihak apabila kejahatan agresi dilakukan setelah satu tahun diratifikasi atau diterimanya Kampala Amendment. Ketika Negara Pihak tidak menerima amandemen, yurisdiksi ICC atas kejahatan agresi tidak dapat dijalankan. Di samping itu, bagi negara yang bukan merupakan Negara Pihak, yurisdiksi ICC atas kejahatan agresi dapat dijalankan apabila negara tersebut melakukan deklarasi kepada Panitera untuk menerima pelaksanaan Yurisdiksi ICC atas kejahatan agresi.

Selanjutnya dalam proses menjalankan yurisdiksi ICC atas kejahatan agresi, apabila Jaksa Penuntut menyimpulkan ada dasar yang masuk akal untuk melanjutkan investigation, ia pertama-tama harus memastikan apakah DK PBB telah memutuskan tindakan agresi yang

${ }^{34}$ Article 8 bis Paragraph 1 and 2 of Rome Statute 
dilakukan oleh Negara terkait. Untuk mendapatkan kepastian tersebut, Jaksa Penuntut memberi tahu Sekretaris Jenderal PBB (Sekjen PBB) tentang situasi di hadapan Pengadilan, termasuk segala informasi dan dokumen yang relevan. Apabila DK PBB telah memastikan tindakan agresi tersebut, Jaksa Penuntut dapat melanjutkan investigation. Namun, apabila setelah 6 bulan pemberitahuan kepada Sekjen PBB tidak ada keputusan yang dibuat oleh DK PBB, berdasarkan wewenang yang diberikan oleh Pre-Trial Chamber dan tidak terdapat putusan dari DK PBB untuk menunda penyelidikan tersebut, maka Jaksa Penuntut dapat melanjutkan penyelidikan tersebut.

Bila dalam Pasal 15 bis mengatur tentang pelaksanaan yurisdiksi ICC atas kejahatan agresi berdasarkan permintaan negara pihak atau prakarsa dari Jaksa Penuntut, maka dalam Pasal 15 ter diatur tentang pelaksanaan yurisdiksi ICC atas kejahatan agresi berdasarkan arahan Dewan Keamanan. Namun, pada dasarnya ketentuan yang diatur dalam Pasal 15 ter sama dengan ketentuan yang diatur dalam Pasal 15 bis. Hanya tentu perbedaannya dalam hal bahwa permintaan penyelidikan atas suatu kejahatan agresi tersebut bukan berasal dari negara pihak atau atas prakarsa oleh Jaksa Penuntut melainkan merupakan arahan dari Dewan Keamanan.

\section{Penegakan Yurisdiksi Internasional Criminal Court atas Kejahatan Agresi}

Kejahatan agresi sebagai international crimes stricto sensu secara jelas mengindikasikan dan memenuhi syarat bahwa agresi juga termasuk dalam kejahatan HAM berat yang bertentangan dengan norma hukum tertinggi dalam hukum internasional. Sebab, kejahatan agresi yang dianggap sebagai kejahatan terhadap perdamaian (crime against peace) tentu terkait erat dengan hak atas perdamaian suatu Negara (right to peace), dan juga hak untuk mempertahankan diri (self defense rights) atas kedaulatan suatu Negara. ${ }^{35}$ Piagam PBB juga memproklamirkan perdamaian dan keamanan sebagai nilai-nilai tertinggi yang patut dihargai. Dalam pembukaan Piagam PBB disebutkan bahwa untuk menghindarkan terjadinya bencana perang, PBB akan menerapkan toleransi dan hidup bersama dalam perdamaian satu bangsa dengan bangsa yang lain sesuai asas bertetangga yang baik (good neighboard). Pada prinsipnya PBB melarang anggotanya melakukan perang terhadap Negara lain. ${ }^{36}$ Kampala Amendments sebagai penegasan bahwa kejahatan agresi menjadi salah satu kejahatan internasional yang berada di bawah yurisdiksi ICC merupakan bentuk perwujudan dari prinsip PBB tersebut.

Dalam Kampala Amendments ditegaskan bahwa keberlakuan dari yurisdiksi ICC atas kejahatan agresi dimulai sejak tanggal 1 Januari 2017 dan berlaku bagi negara pihak pasca satu tahun sejak meratifikasi amandemen tersebut. Sehingga sejak tanggal tersebut dapat dilihat bagaimana yurisdiksi ICC atas kejahatan agresi ditegakkan. Secara aktual, penegakkan yurisdiksi ICC atas kejahatan agresi dapat dilihat dari keseluruhan situasi (situations) dan kasus (cases) yang sedang diproses di ICC yang terdiri dari: 27 Preliminary examinations dengan 10 pada phase ongoing, 4 pada phase closed-decision not to proceed, 13 pada phase completed with decisionn to investigate; ${ }^{37}$ dan 12 Situations under investigate. $^{38}$ Dari keseluruhan situasi dan kasus tersebut, belum ada satu pun yang dikategorikan sebagai kejahatan agresi. Hal ini terjadi sebab tidak ada satupun negara-negara yang yang patut di duga telah melakukan kejahatan agresi pasca Kampala Amendments

35 Noor, T. (2014). “Agresi dan Kejahatan Terhadap Perdamaian”. Supremasi Hukum, 3 (1), h. 43

36 Preambule of Charter of the United Nations, San Francisco, 1945

37 International Criminal Court. (2020). Preliminary Examinations. Retrieved from https://www.icccpi.int/Pages/pe.aspx

38 International Criminal Court. (2020). Situations Under Investigation. Retrieved from https://www.icc-cpi.int/pages/situation.aspx

551 I A A I Vo1. $26 \mathrm{No.4,Oktober-Desember} 2020$ 
diadopsi ke dalam Statuta Roma, telah melakukan ratifikasi atas Kampala Amendment.

Adapun daftar negara-negara peratifikasi Kampala Amendments sejauh ini dapat dilihat dalam tabel berikut. ${ }^{39}$

Tabel 1. Negara-negara Peratifikasi Kampala Amandements

\begin{tabular}{|c|c|c|c|c|c|}
\hline No. & Negara & $\begin{array}{c}\text { Tanggal } \\
\text { Ratifikasi }\end{array}$ & No. & Negara & $\begin{array}{c}\text { Tanggal } \\
\text { Ratifikasi }\end{array}$ \\
\hline 1 & Liechtenstein & 8 Mei 2012 & 21 & Malta & 29 Januari 2015 \\
\hline 2 & Samoa & $\begin{array}{l}\text { 25 September } \\
2012\end{array}$ & 22 & Kosta Rika & 5 Februari 2015 \\
\hline 3 & Trinidad \& Tobago & $\begin{array}{l}13 \text { November } \\
2012\end{array}$ & 23 & Republik Ceko & 12 Maret 2015 \\
\hline 4 & Luxembourg & 15 Januari 2013 & 24 & Swiss & $\begin{array}{l}10 \text { September } \\
2015\end{array}$ \\
\hline 5 & Estonia & 27 Maret 2013 & 25 & Lituania & $\begin{array}{l}7 \text { Desember } \\
2015\end{array}$ \\
\hline 6 & Jerman & 3 Juni 2013 & 26 & Finlandia & $\begin{array}{l}30 \text { Desember } \\
2015\end{array}$ \\
\hline 7 & Botswana & 4 Juni 2013 & 27 & Makedonia Utara & 1 Maret 2016 \\
\hline 8 & Ciprus & $\begin{array}{l}25 \text { September } \\
2013\end{array}$ & 28 & El Salvador & 3 Maret 2016 \\
\hline 9 & Slovenia & $\begin{array}{l}\text { 25 September } \\
2013\end{array}$ & 29 & Islandia & 17 Juni 2016 \\
\hline 10 & Andorra & $\begin{array}{l}\text { 26 September } \\
2013\end{array}$ & 30 & Palestina & 26 Juni 2016 \\
\hline 11 & Uruguay & $\begin{array}{l}\text { 26 September } \\
2013\end{array}$ & 31 & Belanda & $\begin{array}{l}\text { 23 September } \\
2016\end{array}$ \\
\hline 12 & Belgia & $\begin{array}{l}26 \text { September } \\
2013\end{array}$ & 32 & Cili & $\begin{array}{l}23 \text { September } \\
2016\end{array}$ \\
\hline 13 & Kroasia & $\begin{array}{l}20 \text { Desember } \\
2013\end{array}$ & 33 & Portugal & 11 April 2017 \\
\hline 14 & Slovakia & 29 April 2014 & 34 & Argentina & 28 April 2017 \\
\hline 15 & Austria & 17 Juli 2014 & 35 & Panama & $\begin{array}{l}\text { 6 Desember } \\
2017\end{array}$ \\
\hline 16 & Latvia & $\begin{array}{l}\text { 26 September } \\
2014\end{array}$ & 36 & Irlandia & $\begin{array}{l}27 \text { Desember } \\
2018\end{array}$ \\
\hline 17 & Spanyol & $\begin{array}{l}\text { 26 September } \\
2014\end{array}$ & 37 & Guyana & $\begin{array}{l}\text { 28 September } \\
2018\end{array}$ \\
\hline 18 & Polandia & $\begin{array}{l}\text { 26 September } \\
2014\end{array}$ & 38 & Paraguay & 5 April 2019 \\
\hline 19 & San Marino & $\begin{array}{l}14 \text { November } \\
2014\end{array}$ & 39 & Ekuador & $\begin{array}{l}\text { 25 September } \\
2019\end{array}$ \\
\hline 20 & Georgia & $\begin{array}{l}\text { 5 Desember } \\
2014\end{array}$ & & & \\
\hline
\end{tabular}

Dari tabel di atas, yang sangat menarik untuk dilihat tentu dengan ikut sertanya Palestina sebagai negara peratifikasi. Perlu dikathui, meskipun menemui kendala pada saat ingin menaikan status sebagai negara anggota penuh PBB, Pada Rabu 1 April 2015, Palestina

39 the Principality of Liechtenstein and the Global Institute for the Prevention of Aggression. (2020). Status of Ratification and implementation of the Kampala Amendments on the Crime of Aggression. Retrieved from https://crimeofaggression.info/the-role-of-states/status-of-ratification-and-implementation/ 
secara resmi telah bergabung dengan ICC. Peresmian Palestina sebagai anggota ke-123 ICC ditandai dengan upacara sederhana di Den Haag, Belanda, yang dihadiri oleh Menteri Luar Negeri Palestina Riyad al-Malki. Peresmian keanggotaan Palestina di ICC tersebut, dilakukan seletah tiga bulan Presiden Otoritas Palestina, Mahmoud Abbas menandatangani Statuta Roma. ${ }^{40}$

Konsekuensi keanggotaan Palestina di ICC serta ratifikasi yang dilakukan oleh Palestina atas Kampala Amendments ialah semua kejahatan di wilayah Jerusalem Timur, Tepi Barat, dan Gaza sejak 13 Juni 2014 bisa disidangkan di ICC. ${ }^{41}$ Kejahatan tersebut tentunya tidak lagi terbatas pada kehajatan genosia, kejahatan terhadap kemanusiaan dan kejahatan perang, namun lengkap dengan kejahatan agresi. Konsekuensi selanjutnya adalah ICC tidak membutuhkan bergabungnya Israel dalam keanggotaan ICC sebab dalam Pasal 12 ayat (2) huruf a ${ }^{42}$ Statuta Roma tentang Prakondisi bagi Berlakunya Yurisdiksi tertuang bahwa ICC dapat melaksanakan yurisdiksinya apabila korban dari kejahatan tersebut merupakan warga negara dari negara anggota ICC. Pun demikian IC tidak memerlukan ratifikasi Kampala Amendemtns oleh Israel.

Jika kembali pada keadaa aktual tentang situasi di ICC yang belum ada satupun dikategorikan sebagai kejahatan agresi, patut disadari bahwasanya penegakan yurisdiksi ICC atas kejahatan agresi akan memiliki tantangan khususnya terkait pertanggungjawaban oleh individu dari negara agresor. Seperti diketahui, kejahatan agresi cenderung dilakukan oleh negara-negara kuat dan maju. Kencenderungan agresi dilakukan oleh negara-negara yang kuat dan maju dapat dilihat seperti pada intervensi yang dilakukan oleh Perancis dengan menggunakan kekerasan (use of force) di Republik Mali; ${ }^{43}$ agresi militer yang dilakukan oleh Israel terhadap Gaza, Palestina; ${ }^{44}$ dan agresi Amerika Serikat terhadap Irak. ${ }^{45}$ Dengan kecenderungan tersebut, akan sulit untuk membawa individu dari negara agresor bertanggung jawab atas kejahatan agresi yang terjadi. Apalagi individu-individu yang akan bertanggung jawab dalam kejahatan agresi cenderung merupakan individu-individu yang memiliki kedudukan sangat tinggi.

Sekalipun melihat situasi Israel dan Palestina merupakan situasi yang paling memungkinakn untuk dikategorikan sebagai kejahatan agresi, apabila berkaca ke beberapa kasus-kasus yang ada di ICC, untuk dapat menentukan suatu situasi telah terjadi kejahatan

40 BBC. (2015). Palestina Anggota Mahkamah Kriminal Internasional. Retrieved from https://www.bbc.com/indonesia/dunia/2015/04/150401_palestina_mahkamah

41 Mahkamah mempunyai yursidiksi hanya berkaitan dengan kejahatan yang dilakukan setelah berlakunya Statuta ini. Pasal 11 ayat (1) Statuta Roma

42 Dalam hal pasal 13, ayat (a) atau (c), Mahkamah dapat melaksanakan jurisdiksinya kalau satu atau lebih Negara berikut ini adalah pihak dari Statuta ini atau telah menerima jurisdiksi Mahkamah sesuai dengan ayat 3: (a) Negara yang berkuasa atas wilayah di mana perbuatan yang dipersoalkan itu terjadi atau, kalau kejahatan itu dilakukan di atas kapal atau pesawat terbang, Negara di mana kapal atau pesawat terbang itu terdaftar; (b) Negara di mana orang yang dituduh melakukan kejahatan adalah warga negara. Pasal 12 ayat (1) Statuta Roma.

43 Perancis dalam menggunakan use of force tidak berdasar pada otorisasi DK PBB terlebih telah mengakibatkan timbulnya korban jiwa sehingga digolongkan sebagai suatu kejahatan agresi. Lihat dalam Zuhra, N. M. (2020). "Kategorisasi Kejahatan Agresi atas Tindakan Penggunaan Kekerasan Negara Perancis Pada Konflik Republik Mali Dalam Hukum Pidana Internasional". Jurnal Selat, 7 (2), DOI: https://doi.org/10.31629/selat.v7i2.1872, h. 228

44 Tindakan Israel dapat diklasifikasikan sebagai Perang Agresi sebab telah menimbulkan peperangan antara Hamas dan Israel di Gaza. Hamas sendiri merupakan kekuatan politik yang sah di Palestina (Gaza) setelah mereka memenangkan pemilu pada Juni 2007. Lihat dalam Bone, S. (2011). "Urgensi Statuta Roma 1998 Terhadap Kejahatan HAM Dalam Konflik Israel dan Palestina”. Jurnal Amanna Gappa, 19 (3), h. 334

45 Langkah Amerika Serikat untuk menginvasi Irak dapat dikategorikan sebagai kejahatan Agresi setidaknya oleh empat alasan yang diuraikan dalam Wulandari, D. A. (2015). "Agresi Amerika Serikat Terhadap Irak Periode 2003-2010”, Journal of Internasional Relations, 1 (2), h. 133 
internasional khususnya sebagai international crimes stricto sentu akan membutuhkan waktu yang lama.

Terlepas dari situasi penenegakan yurisdiksi ICC atas kejahatan agresi yang bisa dianggap masih berupa ancang-ancang, ketika terdapat satu kasus yang nantinya menuntut tanggung jawab dari individu dengan kedudukan yang sangat tinggi, maka denghan sendirinya stigma yang melekat pada ICC sebagai Mahkamah untuk individu-individu kulit hitam atau dari negara dunia ketiga akan terkikis. Stigma tersebut merujuk pada kasus-kasus yang ditangani oleh ICC di mana hampir seluruh individu-individu yang diadili oleh ICC berasal dari negara ketiga. Definisi Dunia Ketiga biasanya mencakup negara-negara yang pernah mengalami kolonisasi di Afrika, Amerika Latin, Oseania, dan Asia. Dunia Ketiga juga kadang dianggap sama dengan anggota Gerakan Non-Blok. Menurut teori ketergantungan yang dipaparkan oleh Raúl Prebisch. ${ }^{46}$

\section{P E N U T U P}

Berdasarkan analisis terhadap permasalahan dalam penelitian ini diperoleh kesimpulan bahwa berdasarkan Kampala Amendments yang diadopsi ke dalam Statuta Roma, kejahatan agresi didefinisikan sebagai perencanaan, persiapan, inisiasi atau eksekusi, oleh seseorang yang berada dalam posisi yang efektif untuk melakukan kontrol atas atau mengarahkan tindakan politik atau militer suatu Negara, suatu tindakan agresi yang berdasarkan karakternya, gravitasi dan skalanya, merupakan pelanggaran nyata Piagam PBB. Sutau tindakan agresi tersebut berupa penggunaan angkatan bersenjata oleh suatu Negara terhadap kedaulatan, integritas wilayah atau kemerdekaan politik dari Negara lain, atau dengan cara lain apa pun yang tidak sesuai dengan Piagam Perserikatan Bangsa-Bangsa. Setiap tindakan berikut, terlepas dari deklarasi perang, harus, sesuai dengan resolusi Majelis Umum PBB 3314 (XXIX) tanggal 14 Desember 1974.

Penegakan yurisdiksi ICC atas kejahatan agresi yang dilegitimasi oleh adopsi Kampala Amendments ke dalam Statuta Roma belum terlihat secara konkret. Beberapa hal yang mempengaruhi penegakan yursidiksi ICC atas kejahatan agresi antara lain belum banyak negara-negara peratifikasi Kampala Amendments merupakan negara-negara yang cenderung menjadi korban dari kejahatan agresi ataupun sebalikanya negara tersebut sebagai agresor. Diasmping itu kecenderungan individu-individu yang akan bertanggung jawab dalam suatu kejahata agresi merupakan indvidu-indvidu yang memiliki kedudukan sangat tinggi.

\section{DAFTAR PUSTAKA}

\section{Jurnal}

[1] Bone, S. (2011). "Urgensi Statuta Roma 1998 Terhadap Kejahatan HAM Dalam Konflik Israel dan Palestina". Jurnal Amanna Gappa, 19 (3): 324-343.

[2] Ferencz, B. B. (2007). "Enabling the International Criminal Court to Punish Aggression". Washington University Global Studies Law Review, 6 (5).

[3] Gunakaya, W. (2013). "Peranan dan Prospek "Internasional Criminal Court" Sebagai International Criminal Policy Dalam Menanggulangi "International Crimes". Jurnal Wawasan Hukum, 29 (2).

46 Tomlinson, B. R. (2003). "What was the Third World”. Journal of Contemporary History, 38 (2), h. $307-321$

554 |S A S I Vo1. 26 No.4, Oktober - Desember 2020 
[4] Hartono, Bambang dan Hapsari, Recca Ayu. (2019). "Mutual Legal Assistance Pada pemberantasan Cyber Crime Lintas Yurisdiksi di Indonesia”. SASI, 25 (1): 59-71. DOI: https://doi.org/10.47268/sasi.v25i1.136.

[5] Nurhidayatuloh. (2011). "Kejahatan Agresi Dalam Tatanan Hukum Internasional Modern Sebagai Peremptory Norm”. QISTI: Jurnal Ilmiah Ilmu Hukum, 5 (2).

[6] Noor, T. (2014). “Agresi dan Kejahatan Terhadap Perdamaian”. Supremasi Hukum, 3 (1).

[7] Nisa, Candra Ulfatun dan Disemadi, Hari Sutra. (2020). "Yurisdiksi Kriminal Terhadap Black Flight Di Ruang Udara Wilayah Indonesia”, SASI, 26 (3): 365-379. DOI: https://doi.org/10.47268/sasi.v26i3.289.

[8] Suryokusumo, S. (2005). "Agresi Dalam Perspektif Hukum Internasional”. Jurnal Hukum Internasional, 3 (1).

[9] Tomlinson, B. R. (2003). "What was the Third World". Journal of Contemporary History, 38 (2).

[10] Wulandari, D. A. (2015). "Agresi Amerika Serikat Terhadap Irak Periode 2003-2010", Journal of Internasional Relations, 1 (2): 132-140.

[11] Yustitianingtyas, L. (2014). "Pertanggungjawaban Negara Dalam Perspektif Hukum Humaniter Dalam Tindakan Agresi (Studi Kasus: Agresi Israel ke Lebanon Tahun 2006)", $\quad$ Perspektif Hukum, $14 \quad$ (1): DOI: http://dx.doi.org/10.30649/phj.v14i1.30.

[12] Zuhra, N. M. (2020). "Kategorisasi Kejahatan Agresi atas Tindakan Penggunaan Kekerasan Negara Perancis Pada Konflik Republik Mali Dalam Hukum Pidana Internasional". Jurnal Selat, 7 (2): 223-238, DOI: https://doi.org/10.31629/selat.v7i2.1872.

\section{Buku}

[13] Atmasasmita, R. (2006). Pengantar Hukum Pidana Internasional. Bandung: Refika Aditama.

[14] Cassese, A. (2003). Internasional Criminal Law. Oxford: Oxford University Press.

[15] Kittichaisaree, K. (2001). International Criminal Law. Oxford: Oxford University Press

[16] Muladi. (2011). Statuta Roma 1998 Tentang Mahkamah Pidana Internasional Dalam Kerangka Hukum Pidana Internasional dan Implikasinya Terhadap Kerangka Hukum Pidana Nasional. Bandung: Alumni.

[17] Robertson, G. (2002). Kejahatan Terhadap Kemanusiaan: Perjuangan Untuk Mewujudkan Keadilan Global. Jakarta: Komisi Hak Asasi Manusia.

[18] Shaw, M. N. (2008). Hukum Internasional. Cambridge: Cambridge University Press.

[19] Suarda, I. G. W. (2012). Hukum Pidana Internasional Sebuah Pengantar. Bandung: Citra Aditya Bakti.

[20] Widyawati, A. (2014). Hukum Pidana Internasional. Jakarta: Sinar Grafika.

\section{Online/World Wide Web dan Lain-Lain}

[21] BBC. (2015). Palestina Anggota Mahkamah Kriminal Internasional. Retrieved from https://www.bbc.com/indonesia/dunia/2015/04/150401_palestina_mahkamah.

[22] International Criminal Court. (2020). Preliminary Examinations. Retrieved from https://www.icc-cpi.int/Pages/pe.aspx (Diakses pada 24 Januari 2020).

[23] International Criminal Court. (2020). Situations Under Investigation. Retrieved from https://www.icc-cpi.int/pages/situation.aspx (Diakses pada 24 Januari 2020)

[24] Lembaga Studi dan Advokasi Masyarakat. (2015). Kajian Ratifikasi Statuta Roma 1998. 
https://advokasi.elsam.or.id/assets/2015/09/00000000_Kajian_Ratifikasi-statuta-roma1998_ELSAM.pdf.

[25] the Principality of Liechtenstein and the Global Institute for the Prevention of Aggression. (2020). Status of Ratification and implementation of the Kampala Amendments on the Crime of Aggression. Retrieved from https://crimeofaggression.info/the-role-of-states/status-of-ratification-andimplementation/. 